\title{
Conclusions: Why Gibbet Anyone?
}

\begin{abstract}
Given the very high cost of hanging somebody in chains, why was it ever carried out? It was intended to make a deterrent impression on potential criminals and to demonstrate the power and order of the State. However, the many and variable responses to hanging in chains meant that the practice did not always have the intended effect. Gibbetings were infrequent and memorable and served to make the names and histories of those so treated memorable and enduring. Even the very last occasions of hanging in chains were massively popular events, so the distaste expressed by some newspaper commentators was not universally shared.
\end{abstract}

Keywords Costs of gibbeting $\cdot$ Body $\cdot$ Punishment $\cdot$ State $\cdot$ Power

\section{The Costs of Gibbeting}

Gibbeting was an expensive business. We have very good knowledge of the costs from the sheriffs' cravings. Where it is possible to disaggregate the costs of gibbeting from the overall costs of execution, the mean cost per gibbeting of 71 costed cases dating between 1736 and 1799 is $£ 16$, with a range from $£ 210$ s to $£ 5612$ s. There was a considerable asymmetry in costs between gibbeting and dissection. In the Midlands Assizes Court Circuit covering Derbyshire, Leicestershire, Lincolnshire, Northamptonshire, Rutland and Warwickshire (including those hanged

S. Tarlow, The Golden and Ghoulish Age of the Gibbet in Britain, Palgrave Historical Studies in the Criminal Corpse and its Afterlife, DOI 10.1057/978-1-137-60089-9_4 
at Coventry, Derby, Lincoln, Leicester and Nottingham), the average costs reclaimed by the sheriff for organising a basic dissection was $£ 5 \mathrm{ll}$ s by the 1770s. Moreover, in the case of dissection, the sheriff could sell the condemned for a supply fee (of around $£ 5$ ), still reclaim centrally the basic cost of organising the dissection ( $£ 511 \mathrm{~s}$ ), and be actually in profit. ${ }^{1}$

Since the surgeons could make money from staging different types of dissections over a period of up to four days after getting the body, they did not necessarily haggle too much about any supply fees. Surgeons could make as much as $£ 80$ in notorious homicide cases from audience entrance fees; in a less renowned murder case, about $£ 40$ seems to have been average.

Thus, there is a great discrepancy between dissection-potentially quite a lucrative event for both sheriff and surgeon-and gibbeting, which almost invariably meant that the sheriff was out of pocket, since expenses were rarely repaid in full.

Given the expense, the distastefulness and the practical difficulties of gibbeting, in addition to the generally high demand for healthy young bodies supplied at predictable times to the dissection rooms, lecture halls and private parlours of Britain's medical men, why was the spectacle of hanging in chains enacted at all? And why did such a barbaric practice have its period of greatest use and legal enshrinement during the "Age of Reason", in contrast to any hypothetical "civilising process" or triumph of neat self-discipline? How and why did the practice finally come to an end? Finally, what does the historical practice of hanging in chains tell us about attitudes to bodies, to the dead, and to criminals in the eighteenth and nineteenth centuries?

\section{The Murder Act: An Anachronism?}

The Murder Act, notes Cockburn, seems to encapsulate the inconsistent, incoherent and contradictory attitudes towards bodily punishment in the mid-eighteenth century. It nods to both reformist and traditional philosophies of punishment: it extends and enshrines the use of brutal and public punishment at the same time that, for example, punitive whipping was beginning to be taken out of the public arena and carried out in

\footnotetext{
${ }^{1} \mathrm{I}$ am indebted to Elizabeth Hurren for the data on the economics of dissection.
} 
private. ${ }^{2}$ Moreover, the Murder Act formalised in law the well-established practice of hanging in chains, a spectacular and enduring post-mortem punishment, at a moment when such punishment had already passed its peak frequency; gibbeting in Britain would never again reach the levels of the 1740s - the decade before the Murder Act came in.

According to the traditional narrative of punishment, by the mideighteenth century, spectacular and horrific treatments of the criminal body had largely given way to more private and humane bodily punishments. Foucault, for example, sees the replacement of blood-thirsty punishment by reformatory discipline as a form of social control. ${ }^{3}$ By contrast, Spierenberg, while leaving the essential chronological trend intact, thinks that rather than the working of social power, this transformation relates more to a cultural shift of sensibilities through which a new kind of affective and empathetic individualism produced an aversion to public suffering. ${ }^{4}$ The Murder Act was passed during, and was a significant part of, the mid-eighteenth-century crisis in attitudes towards execution. According to McGowen, although there was no major change in practice, perceptions of the event(s) of execution rapidly became more complicated and ambivalent. After the 1750s, says McGowen, "the gallows regime was less securely anchored". The public exhibition of the body, like the public execution, provoked a range of responses, including both an acknowledgement of State power, or of social justice done, and unease or revulsion in the face of human suffering or macabre spectacle.

Steven Wilf interprets the privatisation of punishment as the outcome of an aesthetic preference not to lessen the horror of suffering but to achieve a salutary effect through cultivating the imagination of the crowd rather than stimulating their senses. He dates this process to the 1770 s and ' 80 s, following the failure of an attempt in the 1750s to renew and revivify the spectacle of public punishment. ${ }^{5}$ In this view, the aim of the Murder Act

${ }^{2}$ J.S. Cockburn (1994) 'Punishment and Brutalization in the English Enlightenment', Law and History Review 12(1): 155-79, 171-72.

${ }^{3}$ Michel Foucault (1974) Surveiller et punir: naissance de la prison (Paris: Editions Gallimard). See also Michael Ignatieff ( 1978), A just measure of pain: the penitentiary in the industrial revolution 1750-1850 (New York: Pantheon Books) for a similar argument.

${ }^{4}$ Pieter Spierenberg (2008) Executions and the evolution of repression from a preindustrial metropolis to the European experience (Cambridge: Cambridge University Press).

${ }^{5}$ Stephen Wilf (1993) 'Imagining Justice: aesthetics and public executions in late eighteenth-century England', Yale Journal of Law and the Humanities 5(1): 51-78. 
was "to heighten the terrifying aspect of execution aesthetics". The case of hanging in chains, however, would seem to stimulate both the imagination and the senses of the crowd, as will be discussed below.

The historiography of the body in the long eighteenth century has not dealt directly with the practice of hanging in chains. Cultural historians of the body have concentrated instead on spectacular bodily punishments, including executions devised to maximise bodily pain. The punishments studied by Foucault and others are vengeful, brutal acts carried out on a living body - at least a body that was living at the start of the process. A second tradition of historical interpretation revolves around the practice of anatomical dissection: here the body is dead but it is examined, mapped, known through a nexus of power relations, ritualised performances and scientific curiosity. Hanging in chains does not fit into either tradition of bodily punishment, although it partakes of both.

The practice of hanging in chains, then, might have been intended to accomplish several things:

1. According to the Murder Act, to function as a sufficient "Mark of Infamy" to deter the crime of murder.

2. To make a vivid and salutary impression on the masses.

3. To act as a collective act of restitution and restoration of order.

4. To cement a memory and become part of communal historical knowledge.

5. To demonstrate State power.

The degree to which the gibbet successfully fulfilled any of these functions is unclear but will be considered in this chapter.

\section{The Disappearance of the Body}

The year 1832 marked the end of the age of spectacular post-mortem punishment of the body. After the gibbetings of William Jobling and James Cook that summer, nobody was hung in chains again in Britain. The same year, the Anatomy Act put an end to the punitive, public dissection of criminals, as the bodies of paupers replaced those of malefactors on the dissection table. The corpses of executed criminals would henceforward remain behind the prison walls, buried in a plain and often unmarked grave in the prison burial ground. This transformation in punishment represents a move towards concealing the body from 
public view, a trend that eventually relocated the execution itself to the private space of the prison and excluded the community. ${ }^{6}$ The sequestration of bodily punishment can be placed alongside other narratives of bodily privacy, including the trend towards specialised private spaces for sleeping and washing, the medicalisation of birth and death, and their abstraction from the places of everyday life, and increasingly anxious discourses about sexuality. Prison execution also demonstrates the end of geographically localised punishment. Hanging at the scene of crime was an important part of the eighteenth-century moral economy. In England, this practice was already in decline in the few decades before 1800, although it continued for longer in Scotland. ${ }^{7}$ However, in England outside London, bodies continued to be gibbeted at the scene of crime even when they were executed many miles away, right up until 1832. Whereas hanging in chains at the scene of crime was a strongly community-based punishment, making use of a meaningful location and in turn ensuring that the location remains meaningful in local knowledge, burial inside the prison relocates the body to a "non-place", 8 a space controlled entirely by the State and beyond the reach or experience of the local community.

\section{Hanging in Chains as Deterrent, Retribution or Social Revenge}

The wording of the Murder Act suggests that gibbeting was a public act of sanction: "some further mark of infamy". It was thus retributive in nature. As Radzinowicz points out, a recurrent theme in foreigners' accounts of English justice in the eighteenth century was the harsh nature

\footnotetext{
${ }^{6}$ David Cooper (1990) 'Public executions in Victorian England: a reform adrift' in W. Thesing (ed.) Executions and the British experience from the seventeenth to the twentieth century (Jefferson, N.C.: McFarland) suggests that public execution would have been abolished far sooner were it not for opposition from radicals who wanted full abolition of the death penalty.

${ }^{7}$ Steve Poole 2015 "“For the benefit of example": processing the condemned to the scene of their crime in England, 1720-1830' in R. Ward (ed.) A Global History of Execution and the Criminal Corpse (Basingstoke: Palgrave). For a discussion of Scottish scene-of-crime executions, see Rachel Bennett, unpublished $\mathrm{PhD}$ thesis, University of Leicester 2015.

${ }^{8}$ Although I have used Marc Augé's term here, I do not mean 'non-lieux' as he defines them in the sense of being ephemeral places of super-modernity, but in the sense that a non-place "creates neither singular identity nor relations; only solitude, and similitude" (Marc Augé (1995) Non-Places: introduction to an anthropology of supermodernity (London: Verso), p. 103).
} 
of the criminal code and the severity of punishments to which the convicted were subject. ${ }^{9}$ Post-mortem punishment was thus a result of spiralling inflation of punishment. Extending the kinds of sanction available at the severe end increased the range of possibility and provided a way to distinguish murder or major crimes against the State from less heinous property crimes and crimes against the person which might also result in a sentence of death. As has been noted, when a conviction for damaging the banks of a canal or writing poison pen letters could result in execu$\operatorname{tion}^{10}$ (though it rarely did), some visible and striking sanction for the most serious crimes needed to find a way of being worse than death. This could take the form of a particularly painful or horrific execution, punishment of relatives and associates, or further punishment of the corpse. The first two are also known, although by the eighteenth century bloodthirsty executions were reserved for traitors and often were modified or ignored in deference to changing sensibilities; and the punishment of family members, such as the confiscation of property from the heirs of suicides, was also perceived to be against natural justice and widely circumvented. ${ }^{11}$ Post-mortem punishment represented a rational response exploiting an irrational but almost universal anxiety among the British people of the period about the proper treatment of the dead body.

We can also conclude that punishment which kept the body from normal churchyard burial was intended to be terrible and horrific. Despite the insistence of Protestant theologians on the insignificance of the dead body, and their strong claims that Christian resurrection did not require a whole and unmutilated corpse, the care taken to present a whole, beautiful body for burial only increased from the seventeenth to the nineteenth century. Several trends relating to the care of the dead body over this period are witnessed in the extensive archaeological evidence; these trends include the change from burial in a winding sheet only to the use of a coffin, beautification of the body using hair pieces, wigs, queues, dentures, special grave clothes and decorating the body with flowers

\footnotetext{
${ }^{9}$ Leon Radzinowicz (1990) History of English Criminal Law and Its Administration from 1750, volume 1: The movement for reform (London: Stevens and Sons), pp. 699-720.

${ }^{10}$ D. Hay, 'Property, authority and the criminal law' in Douglas Hay, Peter Linebaugh, John Rule, E P Thompson and Calvin Winslow, Albion's Fatal Tree: crime and society in eighteenth-century England (New York: Pantheon books), p. 17.

${ }^{11}$ Macdonald and Murphy, Sleepless Souls.
} 
and plants. ${ }^{12}$ There is sufficient historical evidence to conclude that the prospect of dissection or hanging in chains was indeed a potent source of dread to the condemned criminal, given the numerous accounts of criminals hearing the pronouncement of their death sentence with equanimity only to fall apart when told that their body would not be returned for burial. When Lambert Reading, for example, was convicted at Chelmsford Assizes in 1775 and sentenced to hang in chains, he begged for that part of his sentence to be revoked in exchange for information about other criminal plans to which he was privy. His request was granted. ${ }^{13}$ Similar accounts of hitherto stoical men collapsing at the horror of being measured or fitted for their gibbet cage are also fairly common. In 1749, Joseph Abseny, a Swedish Catholic condemned for the murder of a servant girl in Bristol, was more troubled by the gibbet part of his sentence than any other and claimed "he did not care if they quarter'd his body so that it was not hung up in the air for Prey to the Birds". Eight years later, John Gatward tried to have the post-mortem part of his sentence altered, although we know from other sources that he was not successful. ${ }^{14}$ Only the hardest of criminals had the sang-froid to quip, as in 1800 James Wheldon the Lancashire mail-robber did on hearing that his body was to be hung in chains, that he was to be thus "made Overseer of the Highways". ${ }^{15}$ Whether this represents a significant change in beliefs about the dead body between the 1750s and the end of the eighteenth century or simply the different attitudes and personalities of the men involved is hard to say. After Theodore Gardelle was hung in chains on Hounslow Heath in 1761, Read's Weekly Journal expressed the view that gibbeting "may appear to some people not as an increase but a mitigation of the punishment as, probably, the dread of

\footnotetext{
${ }^{12}$ Sarah Tarlow (1999) Bereavement and commemoration: an archaeology of mortality (Oxford: Blackwell); Sarah Tarlow (2011), Ritual, belief and the dead in early modern Britain and Ireland (Cambridge: Cambridge University Press); Annia Cherryson, Zoë Crossland and Sarah Tarlow (2012) A fine and private place: the archaeology of death and burial in post-medieval Britain and Ireland (Leicester: Leicester Archaeological Monographs).

${ }^{13}$ London Chronicle, 5-8 August 1775, issue 2912.

${ }^{14}$ London Evening Post, 26-29 August 1749; 14-16 April 1757, issue 4593.

15 The Hull Packet, 29 April 1800, issue 677.
} 
being antomized (as the vulgar term it) has more effect upon the uninformed mind than that of being exposed upon a gibbet". The journal goes on to recommend that remains be gibbeted only after having first been anatomised, which would be a more terrifying prospect and an enduring example to others. ${ }^{16}$

Whether the threat of the knife or the gibbet was sufficient to prevent serious crime in the first place is also unproven. The murder of Jane Grant by Hannah Bocking, committed during a visit to the Derbyshire gibbet of Anthony Lingard in 1818, suggests that a public example of the consequences of murder was not always an effective deterrent. We have found 21 cases of highway robbery committed close to gibbets in the newspapers, one of coining and one of murder. In fact, on the roads into London, robberies right by the gibbets on Hounslow Heath and Wimbledon Common were repeatedly perpetrated in the later eighteenth century, according to newspaper reports.

However, neither its power as a public and cultural statement of retribution nor its intended deterrent effect distinguishes hanging in chains from the alternative of dissection. The question remains: why gibbet anyone?

Perhaps looking at those instances where crimes that did not come into the purview of the Murder Act were punished by hanging in chains can shed light on the meaning of this punishment. Seventy-eight people in England and Wales were sentenced to hang in chains for crimes other than murder between 1752 and 1834. Sixty-four of those were convicted of mail robbery, highway robbery or Admiralty offences other than murder (such as piracy or mutiny). Table 1.2 summarises the crimes punished by hanging in chains in this period. Notably, apart from murder, crimes that threaten the orderly running of the State, such as interfering with the mail, seem to have particularly merited the especially ostentatious punishment of hanging in chains.

Gibbeting is both more public and more location-specific than dissection. Although the public were allowed to view the opened body of the dissected, their window of opportunity was quite limited, in both time and space. The constricted and controlled space of the dissection room could not admit the vast crowds that typically attended a gibbeting, and the gates and doors of the dissection room allowed the crowd to be filtered

\footnotetext{
${ }^{16}$ Read's Weekly Journal, 18 April 1761.
} 
by age, class and gender. ${ }^{17}$ By contrast, the gibbet, typically on common land by the public road, enabled the formation of enormous and unregulated crowds. And their longevity meant that anyone who could not visit on the first day could come on the second, or the following week, month, or even years later. When Mary Hardy of Norfolk visited North Yorkshire in 1765, she made a special trip to see the gibbet of Eugene Aram in Knaresborough 16 years after it had been erected there. ${ }^{18}$

The location of the gibbet, unlike the place of dissection, was rarely determined by practicality or custom. Outside London, where gibbets were placed in the same few locations because of the high numbers involved, and some prominent locations near ports or along the Thames estuary where those condemned for maritime crimes were gibbeted according to Admiralty tradition, most gibbets were carefully located at a site that was close to the scene of crime and highly visible, especially from the public road. The lasting and public nature of hanging in chains as a post-mortem punishment, then, seems to have been considered especially appropriate as a response to crimes that outraged the social contract between citizen and State. The security of the national infrastructure-roads, mail, free trade—was defended by the most visible and exemplary of punishments.

\section{The Body in Chains}

Understanding hanging in chains raises the question: what kind of thing is a gibbeted body? Is it a person? Or is it a thing? Mary Leighton has suggested that dead bodies and human remains occupy an ambiguous position between person and object. ${ }^{19}$ The dead body in early modernity was both a person and a thing: this division aligns with a number of other dualisms relating to the newly dead: sentient/not-sentient, powerful/abject, individual/generic.

The gibbeted body is some sort of thing that can be displayed, used in a discourse of power, and in an affective narrative. It may be that

\footnotetext{
${ }^{17}$ Elizabeth Hurren (forthcoming) 'Time, Spectatorship and the Criminal Corpse in eighteenth and nineteenth century England', Comparative Studies in History and Society.

${ }^{18}$ Mary Hardy's Diary (ed. B. Cozens-Hardy), 1938 (Norfolk Record Society, Vol. 37).

${ }^{19}$ Mary Leighton (2010) 'Personifying objects/ objectifying people: handling questions of mortality and materiality through the archaeological body', Ethnos 75(1): 78-101.
} 
the power of the body to represent a whole biography, a whole self, was especially great in the case of the criminal classes: "their bodies are themselves", wrote one eighteenth-century commentator. ${ }^{20}$ The body in chains is both an abhorrent and a compelling thing. It is part of a life story and-in its landscape-is the medium through which the story is written. It is narrative, moral and illustration.

Zoë Crossland describes four ways in which the dead body is evidence, or rather, four things that the dead body might be evidence of. These are:

1. Body as evidence of the physical or moral state of the individual

2. Body as evidence of the past (in archaeology, for example, or the religious history of relics)

3. Body as evidence of crime, and

4. Body as evidence of the identity of the person.

To understand that fourth category - the dead body as evidence of identity-Crossland turns to Peircean semiotics to ask what kind of sign the dead body is. ${ }^{21}$ Philosopher Kieran Cashell considers that because the dead are absent, signs of the dead are necessarily indexical-holding a relationship with the thing for which they stand. ${ }^{22}$ Thus, for example, the identity of a dead parent is signified, indexically, in her engagement ring. But the body itself is more iconic than indexical-a relationship based on resemblance rather than association. Thus, the dead body itself can stand for its formerly vital counterpart - the living person. Jeremy Bentham conceived the idea that memorials of the dead could take the form of their own preserved and mounted corpses-a form he called the auto-icon. ${ }^{23}$

\footnotetext{
${ }^{20} \mathrm{He}$ was arguing that more brutal physical punishments would make the most effective deterrents.

${ }^{21}$ Zoë Crossland (2009) 'Of clues and Signs: the dead body and its evidential traces', American Anthropologist 111 (1): 69-80.

${ }^{22}$ Kieran Cashell (2007) 'Ex post-facto: Peirce and the living Signs of the Dead', Transactions of the Charles S. Peirce Society 43(2): 345-71.

${ }^{23}$ Jeremy Bentham attached a paper he had written on the principle of the auto-icon to his own will. He left instructions that his own body was to be prepared in that way (F. Rosen, 'Bentham, Jeremy (1748-1832)', Oxford Dictionary of National Biography 2004; online edn., May 2014, http://dx.doi.org/10.1093/ref:odnb/2153).
} 
The gibbeted criminal was a kind of auto-icon, the dead body standing as an iconic sign for the living one. This can work only because the dead body is not the same as the living one-because its deadness moves it at least some of the way from being a person to being a thing.

The executed body is therefore a material thing. Dead bodies in this period are interpreted in different ways according to contexts of discourse. In some discourses, it is de-individualised, universal, medical; in others, it is a highly personalised individual - a signifier of a life. These two tendencies have different historiographies and different meanings and perhaps also constitute the major difference between the alternative postexecution punishments of anatomical dissection and hanging in chains.

Dissection values the body for its universal and biological properties. It anonymises and dislocates the body-gives it no place, no material being; de-personalises and ultimately annihilates it. By contrast, hanging in chains proclaims its individual identity and its particular notoriety. Dressed in its own clothes, preserved with "tar" and displayed on a ten-metre post, the gibbeted criminal becomes an enduring spectacle, a warning and a past of local history. Gibbeting a body transforms the criminal into his own memorial and a mnemonic of his crime. Continually encountered by men and women making ordinary journeys, conspicuous standing gibbets ensured that the stories of those criminals would be remembered and retold. Gibbeting creates a memory that will stick in the minds of witnesses and of everyone who hears about it. The mechanisms by which such a memory is created are five:

1. Gibbeting is relatively unusual, infrequent (averaging only one or two a decade in most counties) and out of the ordinary, so that each occurrence is highly individual and distinct.

2. Associated sensory experiences - the smell of the body, the taste of special holiday treats being sold at the gibbet's foot, the sound of a crowd of thousands or, later, of the creaking chains swinging in the wind. All these things contribute to an embodied and fully sensual memory.

3. By associating the gibbet with conspicuous places in the landscape and ensuring its continued visibility. Siting a memorial on a natural eminence beside a well-used road ensures that it is regularly remarked on and discussed, just as one necessarily notices and remarks on the monumental Gormley sculpture "The Angel of the North" every time one passes its prominent location next to the Al at Gateshead. 
4. Ensuring that witnessing the gibbet is a shared experience. It was made possible for huge crowds of people to attend, so that ongoing discussion and reminiscence kept the memory alive.

5. The occasion of gibbeting was made a shared, public event. By ensuring that the original gibbeting is scheduled and time-bound, it becomes an event to be looked-forward to and then to be reminisced about in company.

Dissection and hanging in chains thus represent two very different strategies for dealing with the body of the dead. Although modern commentators frequently allege that post-mortem punishment drew its force from a belief in the necessity of having a whole body for resurrection, theology of the time does not back this up and it is hard to find any contemporary anxiety expressed on this point. As Richardson has noted, such a view is normally quoted only by contemporary supporters of dissection as a way of mocking the ignorance of its opponents. ${ }^{24}$ However, there is no doubt that, at a popular level at least, considerable emotional importance was attached to treating the dead body "properly" and "decently"meaning careful laying out and graveyard burial.

Both punishments denied the possibility of decent burial and thus are attacks on the body. Equally, both are aimed in some way at affecting secular posterity-the memory of the deceased-although this operated very differently between the two. Dissection, although it had its origins in the demands of medicine rather than in jurisprudence, acted as a form of damnatio memoriae - a way of obliterating the secular posterity of the individual, of stripping away of personhood by reducing the individual to a type - a human body whose specific or idiosyncratic features were of less interest than its ability to stand for a generic and universal medical body. It is an act of active forgetting. The normal ways of marking a death involve fixing the body by making it beautiful, laying it out in a coffin and committing it to a grave. During the eighteenth century, moreover, there is a growing expectation that a burial plot should belong to the interred in perpetuity, that their body should not normally be moved as was common early modern practice. ${ }^{25}$ Dissection takes away

\footnotetext{
${ }^{24}$ Ruth Richardson Death, dissection and the destitute.

${ }^{25}$ Sarah Tarlow Bereavement and Commemoration.
} 
this possibility and gives the body no place to be remembered and inhibits the creation of a beautiful memory for those left behind.

Hanging in chains also affected memory, but differently. Rather than trying to erase the memory of the condemned, it made that memory notorious and inescapable. Whereas anatomised bodies must be depersonalised, divested of individual biography in order to be useful as a teaching aid (in fact, de-personalisation of the body is essential to the medical practitioner's capacity to maintain "clinical distance"), the gibbeted body needs to hang onto its personal narrative to work its full didactic power. Unlike the dissected body, the gibbeted one must retain its individual personhood. It cannot be universal or generic. Where modern technologies of science helped to create a Foucauldian "medical gaze" of powerful bioscience, ${ }^{26}$ the technology of the gibbet facilitated a gaze that shared the theatricality of contemporary anatomy but effected a more personalised and narrative politics of power.

\section{Criminal Tales and Narrative Persons}

One key feature of the gibbeted body, then, is that it possesses narrative. If the body is a sign or index of the person, the manner of its death/ treatment after death completes a narrative of that person. Narratives are never straightforward. They are created and contested to promote particular interests, and the material signs through which narratives are formed can be carefully deployed in attempts to regulate history.

In the case of the gibbeted body, however, the possible interpretations of the signs deployed in the creation of a dominant narrative of power (i.e. the carefully choreographed display of the body by the State to make a statement about the consequences of refusing to obey the law) easily exceed and subvert attempts to make a single dominant narrative. The political and legal Establishment-insofar as there was any consensus-hoped that the sober contemplation of a gibbeted body would make a primarily moral impression on the crowd, re-enforcing a message about the consequences of serious crime. But as we have seen (Chap. 2, "The Carnival of the Gibbet"), other responses were at least equally present. Because the gibbeted body's treatment is so profoundly different

\footnotetext{
${ }^{26}$ S.R. Kaufman and M. Morgan 2005. "The anthropology of the beginnings and ends of life". Annual Review of Anthropology 34: 317-41.
} 
from the treatment of an ordinary dead body, there is some ambivalence in participating as a spectator or crowd member in the carnival of the gibbet. It is thrilling to see, to be physically close to, a dangerous criminal body, but it is also transgressive.

The glamorous appeal of the criminal dead is built on the fame or notoriety of the individual whose body it is/was and the attendant thrill of danger. An encounter with the living body of a criminal-especially a violent one-is dangerous. The potential risk of physical harm, however, is tamed by execution. The criminal corpse still looks like the thing it was but is rendered inert-harmless-by death. The family picnic under the gibbet is analogous to the photograph of a grinning hunter with his foot on the neck of a dead lion: an easy claim to bravery and a bid for contagious glamour.

The gibbeted body is both less and more than a dead human being. It is less because the richness of experience, the animation of life is gone; more because it has acquired symbolic properties that were never present before.

\section{Conclusions: Hanging in Chains}

From the review of hanging in chains covered in this chapter, a few notable elements emerge: first, it was a comparatively infrequent element of punishment. Even when a sentence contained a post-mortem element, whether mandatory or discretionary, it was far more likely to be dissection than gibbeting. Less than $15 \%$ of all crimes falling under the terms of the Murder Act were punished by hanging in chains. Second, it was very expensive. The costs of gibbeting a single criminal could exceed a year's pay for a labouring man. ${ }^{27}$ Third, despite or perhaps because of their infrequency, gibbetings were of huge public interest and often were attended by tens of thousands of people who would journey considerable distances to witness the body gibbeted. It would be fair to describe the events around the hanging in chains as in some ways carnivalesque, when vast crowds were provided with food, drink and entertainment. The magnitude of the event was one thing that made the event and the criminal highly

\footnotetext{
${ }^{27}$ Assuming a day rate of around a shilling a day for 6 days a week and a working year of around 50 weeks.
} 
memorable and significant in local minds. Gibbets were also remembered in the longer term through toponyms, stories and the curation of the material gibbet itself, which could remain in situ for many decades.

What are we to make of hanging in chains? It is an unusual punishment and feels, in the later eighteenth and nineteenth centuries, anachronistic. It has the feel of early modern spectacular and theatrical punishments visited publicly on the body of the criminal. The gibbet is in some ways the spectacular bodily punishment par excellence. The criminal is already dead and the gibbet has no part to play in the actual execution. Nor does it in any way sequester crime from society or protect society from crime. It is pure theatre.

Friedland's recent discussion of Foucault (2012) notes the anthropological intention of Foucault's work on the history of punishment: work that stresses the function of spectacular punishment to be more than an act of terror or an exemplary deterrent. ${ }^{28}$ Instead, Foucault drew attention to the capacity of spectacular punishment to be an act of social restitution, a theatrical and ceremonial event that will in some ways knit up the hole in the social fabric that was rent by the crime itself. In his own analysis of spectacular punishment in France, Friedland argues that public executions should be seen more "as meaningful rituals, which allowed the community at large to find redemption ... than as any kind of display of sovereign majesty" (2012: 13).

Many cases of hanging in chains fit well into just such an explanation: gibbetings, unlike dissections, usually were carried out close to the scene of crime, which tended to be in the murderer's and often the victim's own community, and had the pleasing symmetry that the crime and its punishment happened in the same place.

However, the more anthropological view of spectacular punishment as communal restitution does not mean that it was not also a declaration of State power and a means of negotiating the relationships of power and control by which eighteenth-century British society was structured. Because it was both spectacular and infrequent, the currency of hanging in chains

\footnotetext{
${ }^{28}$ Paul Friedland (2012) 'Introduction: reading and writing a history of punishment' In Seeing Justice Done: the age of spectacular capital punishment in France (Oxford: Oxford University Press), pp. 11-14. Friedland also notes that Foucault's actual discussion does not fully support this position, instead emphasising terror and the need of the State to make a show of their repressive power.
} 
was high. As a demonstration of State power, it certainly would have been highly visible. What such a demonstration accomplished is harder to say.

Ultimately, it is too simplistic to oppose interpretations of the gibbet as either an uncontested demonstration of State power or a communal ritual of popular justice or subaltern subversion. The crowd attending a gibbeting was a diverse body, and whereas some were undoubtedly appalled by the brutality, others were undoubtedly impressed by the moral lesson or titillated by the close encounter with criminal glamour and violent death. Attempts to subvert a State-scripted theatre of power certainly took place but make sense only in a context in which the demonstration of force could normally be expected to make a strong emotional impact.

\section{The Power of Hanging in Chains}

Attitudes towards the gibbet are complex and contradictory. There is a tension between disgust and revulsion on the one hand and fascination on the other. This tension is still evident in the context of contemporary interest in crime history. Brutal physical punishment of the body excites far more public interest than, for example, the history of tax law or boundary disputes. Where gibbet cages survive in museum collections, nearly all are on display and many are among the most popular visitor attractions. The gibbet cages at Moyses Hall, Bury St Edmunds and South Shields Museum are located in the main downstairs galleries, close to the entrance, and visitors to Nottingham's Galleries of Justice encounter a gibbet cage hanging from the ceiling of the atrium.

The popularity of these exhibitions and displays relates in large measure to the taboo-busting power of making visible the invisible interior of the body or of illuminating the normally secret and hidden process of bodily decay. In connection with the first of these, we might note the record-breaking commercial success of Gunther von Hagens's "Body Worlds" phenomenon; in connection with the second, the number of peak-time television dramas that feature prominently the work of forensic scientists examining the taphonomic processes at work on a cadaver. ${ }^{29}$

\footnotetext{
${ }^{29}$ Since the beginning of the Body Worlds exhibition series in 1995 , featuring preserved "plastinated" bodies posed to demonstrate their organs and structure, over 40 million visitors in more than 90 cities worldwide have visited a Body Worlds exhibition (http://www. bodyworlds.com/en/exhibitions/questions_answers.html, accessed 15/6/2015).
} 
But beyond the interest in dead bodies generally, is there particular power attached to the dead criminal body? The criminal corpse is culturally located in the overlap between crime and dead bodies. Both of these areas are deviant, hidden, non-normative. The double dose of transgressive and normally sequestered areas of experience is very effective in stimulating the prurient interests of the public. There were practical reasons for locating gibbets on marginal land, but such places were also symbolically appropriate for the liminal criminal corpse: dead but not buried; a person transformed into a thing; existing, but not living.

Post-mortem punishment gained power through its distance from normal burial and funerary rites. As an ostentatious exclusion from normative mortuary practices, post-mortem punishment ensured that the desired "respectable" and "decent" end was out of the question for criminals. In the period leading up to the Murder Act, it had become a common custom for those criminals able to afford the expense to arrange their own transport to the place of execution in a mourning coach of the kind more usually associated with respectable funerals. Comment in the press opposed this practice on the grounds that it was contrary to the ends of "Ignominy and Shame" which should properly attend such an occasion. ${ }^{30}$

Hanging in chains was an attempt-after the peak period of spectacular bodily punishment - to shame and humiliate the bodies of the most serious criminals. By "making an example" in a carefully choreographed way, the Establishment intended to enforce social conformity in respect of law. But given the polyvalence of the dead body, attempts to produce a certain narrative of crime were never fully regulated. The gibbeted body could be recruited into a number of other stories with a different moral value, including the implication that the State itself was demeaned and barbarous to use such a disgusting and unsubtle punishment. Eventually, the practice had all but died out many years before its final abolition in 1834 .

Hanging in chains, then, was too brutal, ultimately, for the more educated and progressive elements of nineteenth-century British society to be comfortable with. What is more, it had arguably never proved an adequate tool of social control, because the multiple narratives of the

\footnotetext{
${ }^{30}$ London Evening Post, 25 September 1750. As Wilf notes, “The aesthetics of mourning, centered around themes of dignity and honor, undercut the stigma of a public hanging" ('Imagining Justice', p. 58).
} 
criminal corpse were never contained. Instead, the powerful criminal corpse maintained the capacity to subvert or twist any official attempt to harness its power.

Open Access This chapter is licensed under the terms of the Creative Commons Attribution 4.0 International License (http://creativecommons.org/licenses/ by $/ 4.0 /$ ), which permits use, sharing, adaptation, distribution and reproduction in any medium or format, as long as you give appropriate credit to the original author(s) and the source, provide a link to the Creative Commons license and indicate if changes were made.

The images or other third party material in this chapter are included in the chapter's Creative Commons license, unless indicated otherwise in a credit line to the material. If material is not included in the chapter's Creative Commons license and your intended use is not permitted by statutory regulation or exceeds the permitted use, you will need to obtain permission directly from the copyright holder.



